\title{
LEGAL FORMS IN THE BOOK OF THE COVENANT*
}

\author{
By G. J. WENHAM
}

In recent years there have been several studies on Old Testament law. In accordance with accepted principles of form criticism it is quite usual to argue from the form of the laws to their original Sitz im Leben. The first work along these lines was the essay of Albrecht Alt 'Die Ursprünge des israelitischen Rechts', first published in 1934 but still regarded as worth translating into English in 1966. In this article Alt drew attention to the distinction between casuistic and apodictic law in the Pentateuch. He argued that Old Testament case law, 'If a man does $\mathrm{x}$, then ...', was borrowed from pre-existing Canaanite law. ${ }^{1}$ But he argued that in the apodictic law, 'Thou shalt not ...', we have an original creation of Israel, which originated in festivals of covenant renewal. ${ }^{2}$ His argument rested largely on the fact that other Near Eastern legal collections consist almost entirely of case law. Since Alt could not find parallels to apodictic law, he concluded it must be peculiar to Israel.

However, Alt's views have been challenged from various points of view. On the one hand, his classification has been questioned, especially his definition of apodictic law. ${ }^{3}$ On the other hand, parallels to apodictic law have been pointed out in extrabiblical collections of law, ${ }^{4}$ inscriptional curses, ${ }^{5}$

* I would like to thank Mr A. R. Millard and Mr N. J. A. Williams for their helpful comments on this paper, which was read at a meeting of the Tyndale Fellowship in Cambridge, July 1970.

1 A. Alt, Essays on Old Testament History and Religion, Doubleday, New York (1968) 124ff.

${ }^{2}$ Ibid., I 59 ff.

3 B. Landsberger in Symbolae ad iura orientis antiqui pertinentes, Brill, Leiden (1939) 223 f. 19. H. Gese, ThLZ 85 (1960) 147-150. E. Gerstenberger, Wesen und Herkunft des 'apodiktischen Rechts' (WMANT 20) Neukirchener Verlag, Neukirchen (I965) $24 \mathrm{ff}$. G. Fohrer in Studien zur alttestamentlichen Theologie und Geschichte (BZAW I I5), de Gruyter, Berlin (I969) I46f.

${ }_{4}^{4}$ T. J. Meek in $A \mathcal{N} E T, 2183$ f. 24 . R. Yaron, 'Forms in the Laws of Eshnunna' Revue Internationale des Droits de l'Antiquite 3:9 (1962), 137-153; id., The Laws of Eshnunna, Magnes Press, Jerusalem (1969), 56-71. R. A. F. MacKenzie in The 
treaties ${ }^{6}$ and wisdom literature. ${ }^{7}$ It has therefore been argued that Alt was misguided in supposing apodictic legal formulations were a specifically Israelite creation providing a unique insight into Hebrew legal thinking. The new evidence has undoubtedly reopened the question of the origins of Israelite law. But before an answer can be found, it is necessary to reexamine Alt's classification of the Old Testament material.

His division of material into apodictic and casuistic law is based on a combination of stylistic markers and content. Case law 'is invariably introduced by an objective conditional clause beginning "If . . .". Throughout, all those who are concerned in the case under discussion are spoken of in the third personthe person who commits the act and his adversary, and also the judge and God himself.'8 Whenever the rst or 2nd person is used, this is a secondary variation. ${ }^{9}$ Apodictic law is less precisely defined by Alt. It deals with general principles, e.g. the lex talionis. ${ }^{10}$ It makes sweeping generalizations. It refers to Yahweh as judge. ${ }^{11} \mathrm{It}$ is concise and poetic in its formulation: e.g. Whoever strikes a man so that he dies shall be put to death' (Ex. 21:12). Formally this example shows various features characteristic of apodictic law. Its subject is expressed in a participle and the penalty is expressed with a verb and infinitive absolute. ${ }^{12}$ Apodictic law covers the realm of the divine. ${ }^{13}$ Another form in which apodictic law is expressed is the curse: 'Cursed be he who dishonours his father or his mother' (Dt. 27:16). A fine series of such curses is found in Dt. 27.14 Another type of apodictic law is found in the holiness code in Lv. 18:7-1 7: 'The nakedness of $x$ you shall not uncover.' Characteristic of these is the use of the and person singular 'thou' and the negative $x^{3} .{ }^{15} \mathrm{~A}$ large number of the laws in the decalogue fall into this category. Those which do not must be secondary modifications of the primitive form. ${ }^{16}$

Seed of Wisdom, Essays in Honour of T. F. Meek, University of Toronto Press (1964), 39f.

${ }^{5}$ S. Gevirtz, VT II (196r) 137-158; J. G. Williams, VT I4 (1964) 484-489 and $V T$ I5 (1965) 113-115.

${ }^{6}$ G. E. Mendenhall, $B A$ i 7 (1954) 30; F. G. Fensham, $P E Q 93$ (196r) 143-146; D. J. McCarthy, Treaty and Covenant (Analecta Biblica 21), Pontifical Biblical Institute, Rome (1963), 24f., 34ff., 49, 73, 81.
? E. Gerstenberger, op. cit., $62 \mathrm{ff}$.
9 Ibid., 114 .
13 Ibid., 14 Iff.
10 Ibid., 136.
14 Ibid., 147 .
${ }^{8}$ A. Alt, op. cit., $1 \mathbf{r} 3 f$.
11 Ibid., 138.
15 Ibid., $\mathrm{r} 48 \mathrm{f}$.
${ }_{12}$ Ibid., r 40 of.
18 Ibid., $15 \mathrm{rff}$. 
It is obvious that, to a certain extent at least, Alt's conclusions about the origins of apodictic law were implicit in his definition. Because one of the marks of apodictic law is its concern with the realm of the divine, it is not surprising that he concluded that it originated in the cult. Still more fundamental, however, is his presentation of the evidence. By picking out certain distinctive types from different parts of the Pentateuch, he oversimplified the form-critical picture. A fairer view of the situation may be obtained by detailed analysis of a continuous legal text. Since the book of the covenant (Ex. 20:22-23:33) is generally agreed to contain the oldest collection of law in the Old Testament, it seems reasonable to begin here. ${ }^{17}$

In Exodus 2I-22 the commonest form is simple case law expressed conditionally. For instance Ex. 21:26f.: 'When ('כ) a man strikes the eye of his slave, male or female, and destroys it, he shall let the slave go free for the eye's sake. If (ax) he knocks out the tooth of his slave, male or female, he shall let the slave go free for the tooth's sake.' Distinctive features of the form (I) are:

(I) Use of 3 rd person in both protasis and apodosis.

(2) Use of the imperfect or perfect with waw-consecutive in protasis and apodosis.

(3) Use of 5 to introduce the main case (v. 26).

(4) Use of אם introduce subsidiary cases (v. 27).

It happens in this example that there is no change of grammatical subject between clauses, but this is unusual. Other laws in this form are 21 :33f., 35f.; 22:4, 6-8. A slight variation on this form is found in 2I:7-II, where one of the subsidiary protases contains an adjective (2), 21:18f., 20f.; 21:37-22:3; 22:5, I5f., where the apodosis contains an infinitive absolute (3), and 21:20f.; 22:9-12, a negative (4). In 21:28-32 and 22:13-14 all three peculiarities are present.

Another distinctive feature of the syntax of case law is the word order. This follows clearly definable patterns. In a protasis introduced by ' $\supset$, the verb always occupies second place and is followed by subject, object and other modifiers, usually in

${ }^{17}$ For discussion of its date see $\mathrm{H}$. Cazelles, Etudes sur le Code de l'Alliance, Letouzey et Ané, Paris (1946); M. Noth, Exodus, SCM Press, London (1966), 174 ; S. M. Paul, Studies in the Book of the Covenant in the Light of Cuneiform and Biblical Law (VTS 18), Brill, Leiden (1970), 104f. 
this order if they are expressed. ${ }^{18}$ In the following apodosis the verb always occupies second place. It may be preceded by various modifiers including the conjunction waw, the negative particle, or the infinitive absolute. After the verb in the apodosis there is no discernible pattern in the word order. In a protasis introduced by $x$ the verb normally occupies third place in the clause, ${ }^{19}$ as opposed to second place in a apodosis corresponding to an ax-protasis the verb usually comes second, though there are a few exceptions. ${ }^{20}(I)$ These patterns shed light on the use of the infinitive absolute in these laws. The occasional use of the infinitive absolute in an axprotasis simply ensures that the finite verb occupies third place in the clause; it does not lay particular stress on the verb (e.g. 2 I:5; 22:3, I I, I2, I6, 22, 25). Similarly, since the finite verb should come second in the apodosis, the infinitive absolute does not emphasize the action of the finite verb, but may simply mark the beginning of the apodosis. ${ }^{21}(3)$

Sometimes a sub-case of the main or subsidiary protasis may be introduced by 1 instead of (e.g. 2I:3I, 36, 37; 22:9). In these cases $1 \times$ seems to act like a waw-consecutive. Where it immediately precedes the verb the perfect is used instead of the imperfect. Where there is a noun between is and the verb, the imperfect is used $(2 \mathrm{I}: 3 \mathrm{I})$. This change is not dependent on a preceding waw-consecutive, as one might conclude in 21:37; 22:9, since it also appears in 21:36 following an imperfect (5). However unlike the waw-consecutive, I can find no example of the converse, i.e. of an imperfect following where a perfect would be expected. ${ }^{22}$ The order in an $1 \$$-clause depends on whether the preceding protasis was introduced by " Following a 'כ-clause the verb occupies second place (2 1:36f.; 22:9) (5). Following an ax-clause the verb takes third place (2I:3I) (6).

More striking deviations from the pure case law form are

18 Modifiers in case law include the negative particle, waw, prepositional phrases and additional clauses defining a case more precisely. In 22:6, 9 following 'give' the indirect object precedes the direct object.

19 Exceptions to this are $21: 8,19 ; 22: 2,6$ (where the verb is second) and $21: 11$ (where it is fourth).

${ }_{20}$ Twice it comes first, 22:11, 12; twice, third 21:8, 10.

${ }^{21}$ H. Gese, ThLZ 85 (1960) 148 .

22 Examples of 'o-consecutive' outside Ex. $21-23$ include Lv. 4:22f.; 27f.; 5:2If.; 25:49; Nu. 5:14. 
found in $21: 2-6$, where the first clause uses the second person singular (7), and 21:22-23, where the final clause is in the second person singular $(8)$. Use of the second person singular in both halves of the law is found in 23:4f. (9) However, both accord with the rules of word order enunciated above.

A second clearly defined group of laws consists of a participle defining the offence followed by the punishment expressed in the 3 rd person imperfect, usually reinforced by the infinitive absolute $(r o) .{ }^{23}$ This participial construction is found in 21:15, I7; 22:18, 19. Clearly 21:16 falls into the same category; the circumstances are further defined by clauses using wawconsecutive $(I I)$. If the participle is taken as equivalent to and finite verb, the word order conforms to the case law analysed above.

Significant as a form intermediate between the participial construction and the command form is the example of a participle followed by a verb in the 2nd person singular (22:I 7$)(I 2)$. Akin to this are the examples of noun/adjective being followed by 2 nd person imperfect (22:20, 2I) (I3).

A third large category of laws is that of simple commands expressed positively or negatively where no punishment for infringement is specified. This command form covers the bulk of 22:27-23:19, as well as 20:23-24. These laws are always expressed by the second person imperfect not the imperative and are more often in the singular than in the plural(I4). There are two cases where the command is expressed in the third person (23:13, 18) (15), and two examples of formal hybrids between case law and command law (20:25-26; 22:2 I-26) $(I 6)$. It is less easy to discover clear principles of word order in the command form. In positive commands and negative prohibitions the verb may occupy second or third place. In prohibitions the verb may also take third place. ${ }^{24}$

The analysis may be summarized in the following tables.

Abbreviations

i imperfect

Inf infinitive absolute

${ }^{23}$ Ex. 22:19, which does not conform to this pattern, has often been held to be corrupt.

24 This ignores the copula waw, whose use seems indiscriminate in the command form, and 20:24 and 23:10f., where a verb appearing first in its clause is only epexegetic of the preceding verb. 
Md modifier (e.g. waw, negative particle, prepositional phrase, dependent clause N.B. in command form excludes waw but may include up to two other items)

Neg Negative particle

O object

p perfect

P plural

Pt participle

s singular

S Subject

V Verb

w waw

I, 2, 3 Ist, 2nd, 3rd person

( ) Indicates bracketed item optional

TABLE I GRAMMATICAL FORMS

Case Law

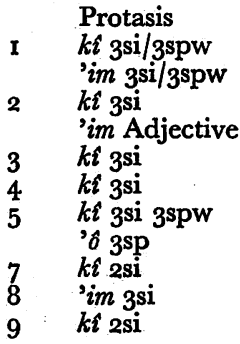

\section{Participial Construction}

\begin{tabular}{|c|c|}
\hline $\begin{array}{ll}\text { ro } & \mathrm{Pt} \\
\text { I I } & \text { Ptw 3spw 3spw }\end{array}$ & \\
\hline 12 (intermediate) & $\begin{array}{l}\mathbf{P t} \\
\text { Noun }\end{array}$ \\
\hline
\end{tabular}

Command Forms

14

15

Hybrid (22:21-26)

16

$$
\begin{aligned}
& \text { 'im Inf } 3 \text { si } \\
& \text { 'im 2si } \\
& \text { 'im Inf } 2 s i \\
& k \hat{\imath} \quad 3^{\text {si }}
\end{aligned}
$$

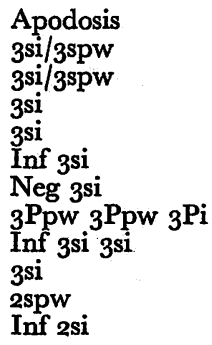

Apodosis

3si/3spw

3 si /3spw

3 si

3 si

Inf 3 si

$\mathrm{Neg} 3 \mathrm{si}$

${ }_{3} \mathrm{Ppw}{ }_{3} \mathrm{Ppw}{ }_{3} \mathrm{Pi}$

Inf 3 si 3 si

3 si

2spw

Inf 2 si

Inf 3 si

Inf 3 si

Neg 2 si

$\mathrm{Neg} 2 \mathrm{~s} / \mathrm{Pi}$

2si

${ }_{2} \mathrm{Pi}$

Neg 2si

$\mathrm{Neg} 2 \mathrm{Pi}$

Neg 3 si

Neg $2 \mathrm{Pi}$

Neg ('im) Inf 2 si

Inf rsi 3spw ispw ${ }_{3} \mathrm{Ppw}$

Neg 2 si Neg $2 \mathrm{Pi}$

2 si

Ispw

Case Law

TABLE 2 WORD ORDER

\section{Protasis}

I General Pattern

$$
k \hat{i}+\mathrm{V}+(\mathrm{S})+(\mathrm{O})+(\mathrm{Md})
$$$$
\text { ' } i m+\mathbf{M d}+\mathbf{V}+(\mathbf{M d})
$$

Apodosis

$$
\mathbf{M d}+\mathrm{V}+(\mathbf{M d})
$$

$\mathbf{M d}+\mathbf{V}+(\mathbf{M d})$ 


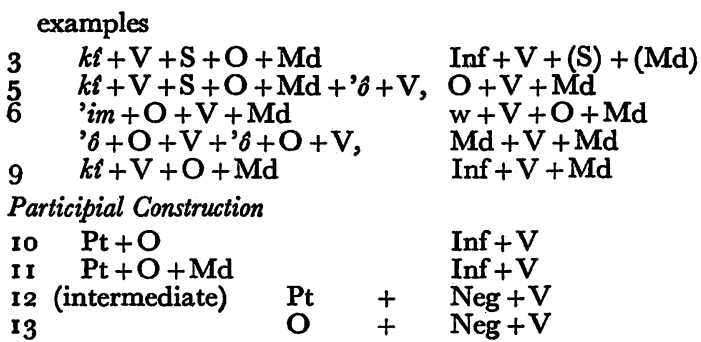

\section{Command Form}

I4 General Pattern

examples

I5

Hybrid (22:21-26)

I6

$$
\begin{aligned}
& \operatorname{im}^{\prime}+\operatorname{Inf}+\mathrm{V}+\mathrm{Md} \\
& { }_{i m}+\mathrm{O}+\mathrm{V}+\mathrm{O} \\
& { }^{\prime} i m+\operatorname{Inf}+\mathrm{V}+\mathrm{O} \\
& k \boldsymbol{t}+\mathrm{V}+\mathrm{Md}
\end{aligned}
$$

$M d+V+(M d)$ (n.b. $M d$ may contain two elements in command form e.g. Neg + Inf but excludes waw)

$$
\begin{aligned}
& \mathrm{O}+\mathrm{Neg}+\mathrm{V} \\
& \mathrm{O}+\mathrm{V}+\mathrm{Md} \\
& \mathrm{Neg}+\mathrm{V}+\mathrm{O} \\
& \mathrm{Neg}+\mathrm{V}+\mathrm{Md}
\end{aligned}
$$

$$
\begin{aligned}
& O+N e g+V \\
& N e g+I n f+V+O+M d \\
& \text { Inf }+V+O+M d \\
& N e g+V+M d \\
& \text { Neg }+V+M d+O \\
& M d+V+M d+M d \\
& w+V+M d
\end{aligned}
$$

This analysis of the legal forms in the book of the covenant shows the complexity of the situation. On the one hand it is possible to discern clear patterns into which its three main types of law fall. On the other hand there are a number of forms which do not fall neatly into any category, but seem to be a mixture. Further clarification will have to await analysis of other corpora of biblical and Near Eastern law. But for the moment the principles which have been elucidated must serve as a working hypothesis in the further analysis of these laws. On this basis three conclusions may be drawn:

First, the Revised Standard Version and New English Bible are wrong in their reparagraphing of Ex. 21:37-22:3, since as they stand these verses conform to the general patterns used in formulating case law, but not in the translators' rearrangement. ${ }^{25}$

${ }^{25}$ By marking as a new paragraph a clause introduced with ' $i m$, the translators miss the significance of $k \hat{i}$ and 'im. Further, the rearrangement entails repeating the penalty for the offence of stealing an ox or sheep and omitting to state the penalty for killing a housebreaker. M. Greenberg points out too that the suggested rearrangement fails to take note of the modification of traditional law ( $c f . \mathbf{C H} 8$ ) which is here being introduced in Exodus, see $r$. Kaufmann Jubilee Volume, Jerusalem (1960), 18 f.26. 
Second, the participial formulation should be regarded as a sub-group of the normal case-law type. The participle does duty for second part of case merely marks the opening of the apodosis. Pace Alt, it is not a poetic device emphasizing the action of the finite verb. Hence the participial construction should not be regarded as apodictic law.

Third, since there is a considerable overlap between caselaw formulations and command forms, we must be cautious about assigning them to different Hebrew life-settings, whatever their earlier origins may have been. ${ }^{26}$

${ }^{26}$ Besides treaties and the Laws of Eshnunna ( $c f$. footnotes 4 and 6) another legal text showing a diversity of legal forms within a single document is the Edict of Ammi-saduqa. See F. R. Kraus, Ein Edikt des Königs Ammi-Saduqa von Babylon (Studia et documenta ad iura orientis antiqui pertinentes 5), Brill, Leiden (1958), 182ff., and the more complete text given by J. J. Finkelstein in $A N E T^{3} 5_{26-528}$. 